\title{
The role of district heating in the future Danish energy system
}

Münster, Marie; Morthorst, Poul Erik; Larsen, Helge V.; Bregnbæk, Lars; Werling, Jesper; Lindboe, Hans henrik; Ravn, Hans

\section{Published in:}

Energy

Link to article, DOI:

10.1016/j.energy.2012.06.011

Publication date:

2012

Document Version

Peer reviewed version

Link back to DTU Orbit

Citation (APA):

Münster, M., Morthorst, P. E., Larsen, H. V., Bregnbæk, L., Werling, J., Lindboe, H. H., \& Ravn, H. (2012). The role of district heating in the future Danish energy system. Energy, 48(1), 47-55.

https://doi.org/10.1016/j.energy.2012.06.011

\section{General rights}

Copyright and moral rights for the publications made accessible in the public portal are retained by the authors and/or other copyright owners and it is a condition of accessing publications that users recognise and abide by the legal requirements associated with these rights.

- Users may download and print one copy of any publication from the public portal for the purpose of private study or research.

- You may not further distribute the material or use it for any profit-making activity or commercial gain

- You may freely distribute the URL identifying the publication in the public portal

If you believe that this document breaches copyright please contact us providing details, and we will remove access to the work immediately and investigate your claim. 


\title{
The role of district heating in the future Danish energy system
}

\author{
Marie Münster ${ }^{*}{ }^{a}$, Poul Erik Morthorst ${ }^{\mathrm{a}}$, Helge V. Larsen ${ }^{\mathrm{a}}$, \\ Lars Bregnbæk ${ }^{\text {', Jesper Werling }}{ }^{\mathrm{b}}$, Hans Henrik Lindbo ${ }^{\mathrm{b}}$, \\ Hans Ravn ${ }^{c}$, \\ a: Risø DTU, Frederiksborgvej 399, DK-4000 Roskilde, Denmark. \\ E-mail:maen@dtu.dk \\ b: Ea Energianalyse a/s, Frederiksholms Kanal 4, 3. th., DK-1220 Copenhagen K, Denmark. \\ E-mail: 1b@eaea.dk \\ c: RAM-løse edb, Æblevangen 55, DK-2765 Smørum, Denmark. E-mail: \\ hans.ravn@aeblevangen.dk
}

\begin{abstract}
In the EU and in Denmark, the aim is to reduce dependence on fossil fuels and to use energy more efficiently. District heating and combined heat and power has significant potential with regard to achieving this aim. New technologies may make individual solutions such as electric heating, heat pumps and micro-CHP more attractive than previously. Therefore, the competitive conditions between district heating and other types of heating may change in the future. The question is therefore whether district heating can contribute to ensuring the sustainability of future energy systems? Denmark is used as a case as the country has a high share of district heating and produces $20 \%$ of the electricity with wind power. The analyses are carried out using the electricity market model Balmorel, which facilitates cost optimization of operation and investments in energy production plants as well as electricity transmission. To be able to perform the analysis an extension of the model is developed, where it is also possible to optimize between investments in individual heating plants or in expansion of the district heating networks, depending on investment costs, energy density of the potential areas and their distance to existing district heating networks. Results show that district heating may contribute to the sustainability and security of supply of future energy systems and that under the given assumptions it is cost effective to increase the share of district heating up to $55-57 \%$ of the heat demand although substantial heat saving measures are installed.
\end{abstract}

Keywords: District heating; optimization; energy system analysis

\section{Introduction}

In general the European Community is facing three major challenges within the energy field [1]:

- Sustainability. Current energy and transport policies imply that EU CO2 emissions are to rise by approx. $5 \%$ by 2030 . Global emissions are expected to increase by $55 \%$ in the same period if no actions are taken.

- Security of supply. Europe is increasingly becoming more dependent on imported fuels. A continuation of existing trends will imply that the present import share of $50 \%$ will increase to approx. $65 \%$ in 2030 . This implies a high vulnerability of the energy system, e.g. in relation to terrorism.

\footnotetext{
${ }^{*}$ Corresponding author. Tel.: +45 46775166; fax: +45 46775199.

E-mail address: maem@dtu.dk (M. Münster).
} 
- Competitiveness. Rising energy prices could jeopardize additional job creation in the EU. Investing in energy efficiency and renewable energy could induce innovation and industrial development benefiting employment and the economy in the EU.

In facing these challenges the EU member states by 2008 adopted long term targets in three different areas of energy policy: 1) The EU has agreed on a binding reduction of greenhouse gases of $20 \%$ by 2020 compared to 1990; this target can be raised to $30 \%$ subject to the conclusion of binding international climate change agreements. 2) A mandatory target for the development of renewable energy sources; by 2020 20\% of final energy demand in EU has to be supplied by renewable technologies as wind power, solar and biomass. For Denmark the target is 30\%. 3) A voluntary agreement on energy efficiency with the objective of saving $20 \%$ of EU energy consumption by 2020 compared to a reference projection. Finally, EU has a target of achieving a share of $10 \%$ of renewable sources including biofuels in transport by 2020. In Europe the achievement of these targets requires a development which is driven both by national and EU policies [2].

This new policy relying to an increasing degree on renewable sources are going to change the European energy systems radically within the next decade. Energy technologies based on variable sources, especially wind power and photovoltaic, are expected to have a large role to play in the future energy supply. In Denmark wind power is by 2020 expected to supply 50\% of Danish electricity consumption implying that from time to time wind power will produce more power than needed in the Danish system. Certainly this is a challenge that will not only require significant changes in the overall energy system, but will also require close interactions with the large energy system infrastructures such as the district heating network.

\section{Danish energy policy and district heating}

For more than a quarter of a century Denmark has developed a environmentally strong profile with regard to development of the energy sector and since the beginning of 1990s the problem of Climate Change has been the most important driving factor behind the Danish energy policy. Thus, as part of the EU Denmark has a commitment or reducing its emissions of greenhouse gases by 21 percent on average in the period 2008-2012 as compared to 1990 . However, Denmark is one of those countries that want to go even further.

In 2008 the Danish Prime Minister announced a vision of a Denmark being independent of fossil fuels in the long term time perspective, thereby not only improving our security of energy supply but also significantly reducing our GHG-emissions. This vision led to the establishment of the Danish Commission on Climate Change policy which by September 2010 launched its report, stating that by 2050 a Danish energy system independent of fossil fuels is achievable without excessive costs to society [3].

In February 2011 the Danish Government launched its follow-up report; the official plan entitled Energy Strategy 2050. The Energy Strategy suggests a number of policy initiatives for phasing out fossil fuels in the long term [4]. Naturally, such a long term development requires significant changes in the structure of the energy system, as well as a continued use of strong policy measures.

District heating has a major role to play in these long term scenarios for the future energy system. The Danish energy system is today characterised by a very diversified and distributed 
energy generation based upon three major national grids; the power grid, the district heating grid and, finally, the natural gas grid. The combined utilization of these grids has implied that we have a highly efficient supply system with a high share of combined heat and power. The increased production of renewable energy in the future, primarily wind energy, must as effectively as possible interact with these grids in order to contribute as much as possible in the displacement of fossil fuels in the electricity, heat and transport sectors and in this respect district heating will be a key concern. This article focuses on the use of district heating in 2025 as a step toward a fossil free future.

\section{Efficient district heating in the future energy system project}

Today approximately $60 \%$ of the Danish heating needs are covered by district heating and approximately $45000 \mathrm{~km}$ of district heating pipes are buried in the Danish ground. As shown in Figure 1 a large part (80\%) of the district heating supply is being produced in combination with electricity on combined heat and power plants (CHP), large scale CHP units accounting for a little less than $50 \%$ of the district heating supply, while small scale CHP supplies approximately $20 \%$.

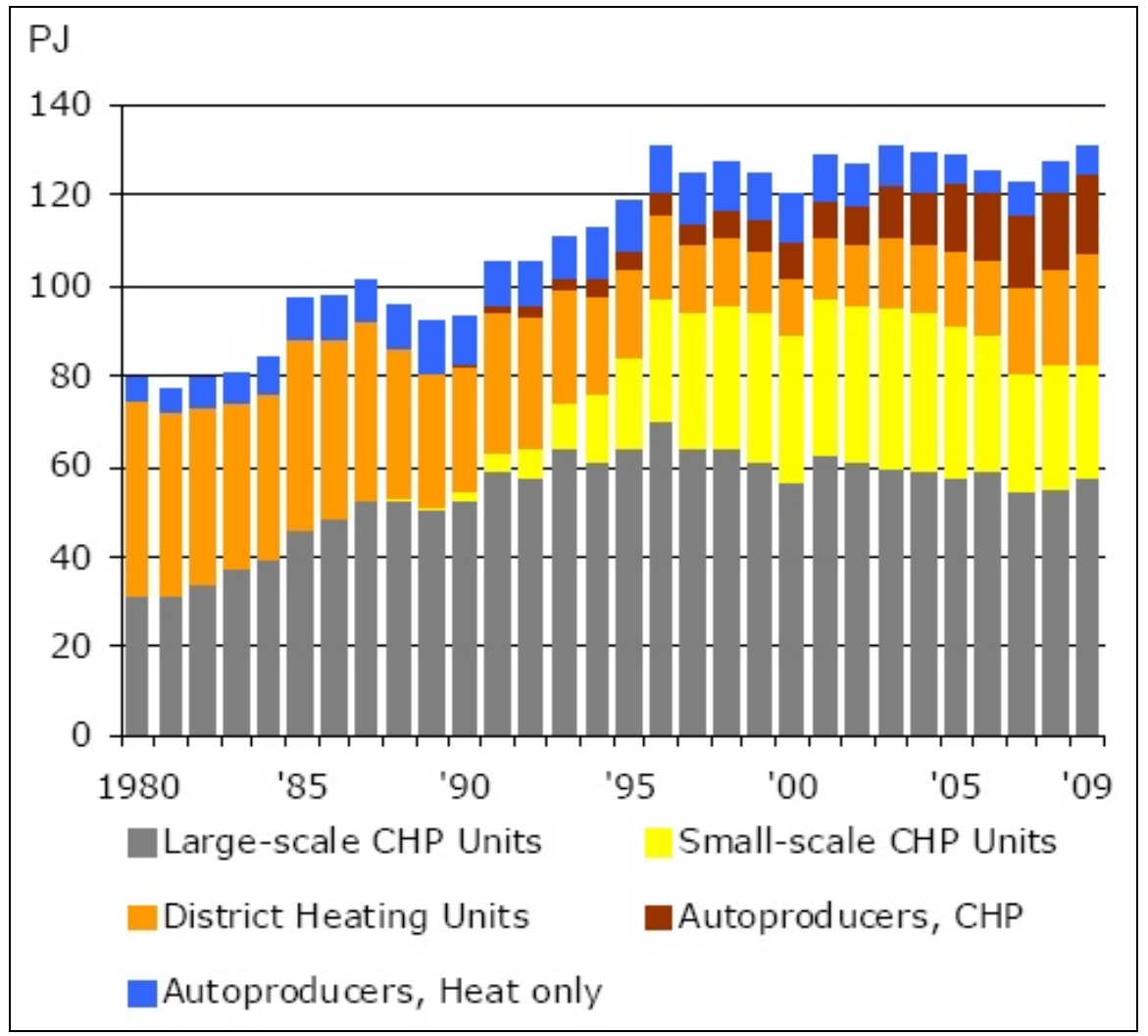

Figure 1. Production of district heating in Denmark by type of producer [5]

A variety of fuels are used in the district heating supply. More than $40 \%$ of fuel consumption is based on renewable sources, mainly biomass, while natural gas has a share of approximately 25\%. The rest is accounted for by coal and oil. The variety of fuels is one of the major advantages of the district heating concept: No matter how the heat is produced it will in most cases be possible to absorb and distribute it through a district heating network. 
Looking at the future role for district heating the following trends might be some of the dominant ones:

- Large heat pumps may be installed in the district heating network utilizing excess power production from wind turbines when there is plenty of wind. The district heating system may then act as storage facility using the existing hot water storage tanks but also utilizing the large amounts of water in the grid as a buffer.

- The existing CHP-production on large scale coal-fired power plants may gradually be converted to biomass or decommissioned implying that a smaller part of the district heating supply would be covered by CHP. Thus, new supplies of district heating based on renewable sources would have to be introduced into the energy system. However, also an increased utilization of waste heat from industrial processes could be utilized through the district heating system.

- In general, increased insulation and refurbishing of buildings will imply lower heating needs and thus also a lower demand for district heating. However, in Denmark this may to a certain extent be moderated by today's natural gas supplied buildings being converted to district heating or to other individual heating technologies such as heat pumps.

In the following sections a number of scenarios will explore the possible impact of these trends and outline the future of district heating in Denmark.

\section{Investing in district heating networks}

To clarify the role of district heating in a future energy system it is interesting to include district heating network expansion as part of an optimization to clarify the future competition between collective and individual heating options in a situation with changing framework conditions such as reduced heat demand per square meter and increased wind power resulting in less CHP production.

Only few studies have been found, which combine optimization of investment and operation in heat and power supply technologies with investment in district heat transmission networks [6-10]. All of these however focus on local or regional energy networks and not on national energy systems. In this article the aim is to explore the role of district heating in a future national energy system making it possible to optimize the national use of resources such as wind as well as electricity trade with neighbouring countries. Therefore an analysis in a national energy system model is necessary.

Formerly, national energy system models have been used to analyze scenarios of various expansion levels of district heating networks. In these cases network expansion is not taken as a variable to be optimized. One example of this is an application of the EnergyPLAN model, where investments are fed in as exogenous input to the model [11]. In the analysis a heat atlas is used to identify potential expansions of district heating networks [12,13]. This approach was found to be compatible with the research objectives of the study presented in this article. Using the same heat atlas it was possible in this study to perform a national level combined optimization of operation and investments of energy production and transmission - including both electricity and district heating transmission. Apart from the present article, which describes the model functionality and goes into detail with results regarding the role of district heating, the model feature has also been used for two other studies. Here the focus is however strictly on different uses of waste for energy [14,15]. 
The heat atlas was originally sketched in the project "Information Systems for Energy Planning” [16]. The version applied for these analyses was developed for Heatplan Denmark for the Danish District Heating Association. The heat atlas is based on extractions from the Danish national Building and Houses Database (BBR) from March 2006 [17], which contains data for physical properties, administration and ownership of all buildings in Denmark. These data are supplemented with data from energy certificates for dwellings and for heat demands in the commercial, service, industrial and farming sectors. The net heat demand from the Danish Energy Statistics is used for validation of the heat demands calculated in the heat atlas [18].

\subsection{The Balmorel model}

The Balmorel model [19] is a model that simulates investment and operations of a combined electricity and CHP system in an international perspective. It permits integrated analyses of demand and supply of electricity and heat while balancing operation against investment, local electricity generation against import/export of electricity, and price elastic demand against generation and investment. It represents demand of electricity and heat in a number of geographical locations, each with individual time variations within the year. Demand may be price responsive, such that higher prices will tend to reduce consumption.

Supply of electricity and heat are given by generation technologies of which there are modelled different basic types, including CHP types (backpressure and extraction), heat pumps, storage types (electricity and heat), and renewable types (hydro, wind, solar). Electricity transmission between regions is constrained by available capacities, while distribution of electricity and heat are represented by losses and costs.

The subdivision of the year into smaller time steps is flexible, ranging from analysis on hourly to annual values; the subdivision is typically chosen according to the needs of the specific application. The time span to be analyzed may range from a part of a year (e.g., a week), typically for operational analysis, to a number of years (e.g., 2010 through 2030), typically for investment analyses.

For investments analyses the investment decisions are made with integrated representation of operation and investment costs, reflecting the facts that investment and operation cannot be separated. Investments may be made in generation technologies and in electricity transmission capacity.

Key input are existing electricity and heat generation capacities, electricity transmission capacities, demand, i.e., the kind of data implied by the above description. Additional key assumptions relate to fuel prices, $\mathrm{CO} 2$ costs, taxes and support schemes. Main output is consumption, production, electricity transmission, emission and other physical key information. As the model is an optimization model, marginal costs on restrictions are available; these costs may, with appropriate additional assumptions, be interpreted as prices.

The model is formulated as a deterministic linear optimization model in the GAMS modeling language [20]. This permits changes and adaptations of the model to specific applications that are not presently covered by the standard version of the model. The model's GAMS code is available at open source conditions at www.Balmorel.com. This permits any user to download the model, apply it and modify it for application in specific projects, a feature that was exploited in the present study. 


\subsection{Marginal cost curves}

Using the heat atlas, it was possible to generate curves of increasing marginal cost of grid expansion for the district heating expansion potential consisting of: 1) a possible densification of areas already defined as district heating areas in the municipal planning, 2) areas bordering up to existing district heating areas and 3) areas within a maximum of $1 \mathrm{~km}$ 's distance to district heating areas. To keep the model linear, the curves were approximated in 9 piecewise constant intervals as illustrated in Figure 2 for West Denmark. The figure illustrates that it becomes more expensive to supply district heating for an area the less the heat density is in the area. The lowest increase in marginal costs is found in areas which are currently supplied by small gas fired plants as they have high heat densities compared to the costs of grid expansion.

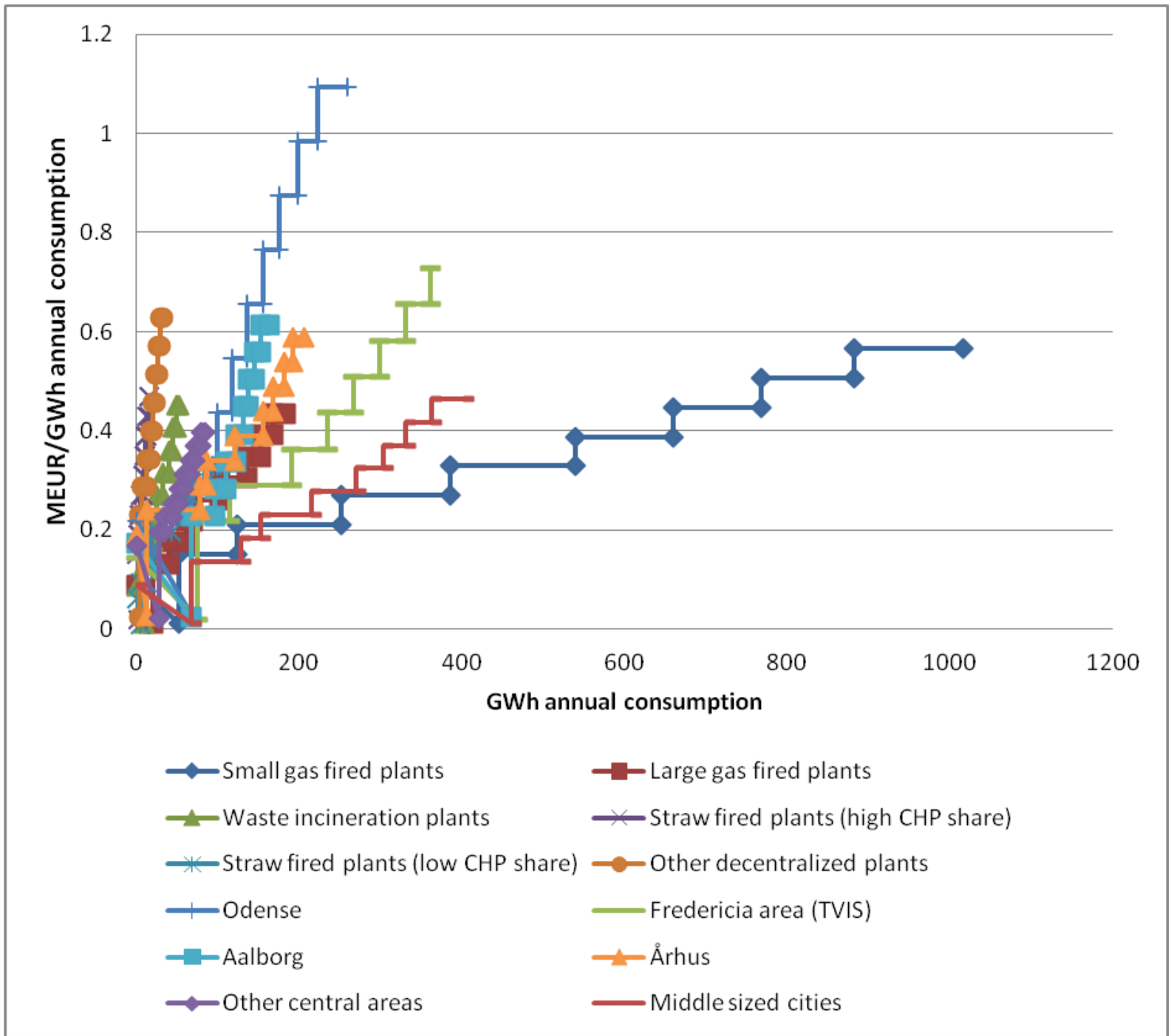

Figure 2. Marginal expansion cost curves for West Denmark

The heat atlas specifies net heating demands (heating and hot water) according to the buildings' current heating technology and topographical position related to district heating networks and the area specified in Balmorel in which the heating demand occurs. The Balmorel district heating areas are geo tagged based on a data base on the existing district heating networks and their heating supply technologies. Some of these areas relate to the 
district heating networks of greater cities and some are aggregated according to current heating technology.

The district heating grid expansion costs are calculated for each building based on prices on pipes and labour [21] as well as on geographical variables such as the buildings' heat demand, the type of building area and the distance to the nearest existing district heating network. The cumulative district heating potential is related to the marginal district heating expansion cost curves, which take into account distance and cost level depending on how densely populated the area is. The cost curves are separated into different types of production technologies of the different Balmorel areas. There is hence one cost curve for all areas supplied by waste incineration CHP plants etc.

Areas of heat demand were created in Balmorel and defined as adjacent to the existing district heating systems, both the systems represented individually, and those which were aggregated from similar systems. These adjacent system were endowed with sufficient capacity of individual heating technologies to cover peak-load in 2010, but these capacities were gradually depreciated and the model would then be able to choose the replacement heat source from a catalogue of individual heating technologies and investing in network expansion from the nearby district heating network, which where investments in boilers, CHP-units and heat pumps were also permitted. While DH technologies are able to combine to make an efficient balance of base and peak heat load, any installed individual heating capacity was required to generate according to the load profile.

Thereby, the model can find an optimal balance between alternative supply options:

- Optimized use of existing technologies, including individual heating capacity and district heating technologies.

- The option to invest in new capacity in both individual heating supply and district heating technology.

- And finally, move the border between areas supplied by district heating and individual heating based on the cost of these supply options and the cost of network expansion.

Table 1 shows supply options for buildings which currently have individual heat supply. The model does not, however, account for the option to establish green field plants, and as such the level of district heating expansion is constrained to a maximum of $70 \%$ of the net-heat consumption in Denmark. Nor does the model have the option to decommission the district heating supply in existing areas. Given the results presented in the section on scenarios, where district heating is expanded, this omission does not appear to be of vital importance. 
Table 1. Supply options for buildings which currently have individual heat supply

\begin{tabular}{ll}
\hline Existing supply & $\begin{array}{l}\text { The model has exogenous capacity distributed } \\
\text { on individual and natural gas furnaces. The } \\
\text { exogenous capacity is written down linearly } \\
\text { over } 15 \text { years, which is assumed to be the } \\
\text { expected lifetime of these individual furnaces. }\end{array}$ \\
\hline $\begin{array}{l}\text { New individual } \\
\text { supply capacity }\end{array}$ & $\begin{array}{l}\text { It is possible to install either a new oil or gas } \\
\text { furnace. Natural gas is however constraint to } \\
\text { the total capacity in the outset as the option to } \\
\text { extend the gas networks has been forgone in } \\
\text { this study. Alternatively, individual ground- } \\
\\
\text { source or air-source heat pumps can be } \\
\text { installed. }\end{array}$ \\
\hline District heating & $\begin{array}{l}\text { It is possible to invest in a connection to the } \\
\text { nearby district heating system. In this system } \\
\text { new CHP-units, boilers, heat-pumps and heat } \\
\text { storages can be installed. }\end{array}$ \\
\hline
\end{tabular}

From the model's perspective, the advantage of individual over communal supply options is the avoided investment in DH-networks, the heat losses incurred in $\mathrm{DH}$ pipelines, and possibly the relative cost of individual technologies.

The advantage of communal supply is the economies of scale in installed technologies and the possibility to pool technologies and thereby have higher utilization on capital intensive technologies, while peaking with relatively energy intensive technologies. Relatively inexpensive heat storages can be efficiently integrated in the system to ensure efficient integration with the power market. Finally, the fuel costs are less for communal supply options, which naturally will be weighed against the additional $\mathrm{DH}$ infrastructure costs and losses.

\subsection{Modelling network expansion and competition with individual heating technologies}

The Balmorel model is well documented e.g. in Ravn [19] and in Münster and Meibom [15]. In the following, the additional model components are documented in terms of their mathematical formulation.

The nomenclature of this section is as follows:

\section{Sets}

- $i, j$ describe areas in the model. The subsets $D H$ refer to the areas which presently has district heating and IND refers to the subsets of areas, which presently have individual heating, but where districtheating could be extended.

- $t$ represents the timesteps in the model.

- $s$ represents discrete steps in the district heating supply expansion cost curve (See Figure 2).

- $\operatorname{Adj}(i, j)$ tupple set indicating that area $i$ is adjacent to area $j$, thereby allowing network expansion from $i \in D H$ to $j \in I N D$. 
- $g$ represents generation technologies. These are constrained by subsets $G^{I N D}$ and $G^{D H}$ for individual heating technologies and district heating technologies.

\section{Parameters (exogenous)}

- $p_{t}$ is the time variation in heat demand, i.e. the percentage of annual demand to fall into time periode in capacity terms.

- $d_{i}^{t}$ is the exogenous heat demand in area $i$ at time $t$.

- $\operatorname{loss}_{i}$ is the heat distribution loss factor in area $i$.

- $I_{i_{i} j}^{S_{s} M i n}$ is the minimum level of network expansion possible between $i$ and $j$ at the cost of step s. This will be zero in the first year, or the level of expansion achieved in a previous year.

- $I_{i_{i} j}^{s_{s} \text { Max }}$ is the maximium level of network expansion possible between $i$ and $j$ at the cost of step $s$.

- $a$ annuity factor used to annualise investment costs.

- $C_{i, j}^{s}$ is investment cost of expanding with district heating supply from area $i$ to area $j$.

\section{Decision variables (endogenous)}

- $x_{i, j}^{t}$ is the distribution of heat from $i$ to $j$ at time $t$.

- $h_{i, g}^{t}$ is the generation of heat from at $i$ on technology $g$ at time $t$.

- $L_{j, g}$ is the level of generation of generation in relation to heat demand over the year supplied by the individual technology $g \in G^{I N D}$ in area $j \in I N D$.

- $S_{i}^{t}$ is the loading of storage in area $\mathrm{i}$ at time t.

- $Z$ is the objective function variable

All decision variables are positive and continuous, with the exception of the objective function variable.

Transmission into adjacent area limited by invested capacity (MJ/s)

$$
x_{i, j}^{t} \leq \sum_{s} I_{i, j}^{s} p_{t} \forall i, j \in \operatorname{Adj}(i, j), t
$$

Transmission from $\mathrm{i}$ to $\mathrm{j}$ is in each time step constrained by the level of investment performed and the time variation of heat demand. The time variation is included since heat is supplied to an area representing an aggregation of consumption points (households, industries, etc.). The investments are defined on a capacity basis and therefore, were the supply not restricted by the consumption profile, the model would be able to supply consumers not connected to district heating system when the system is off peak.

\section{Supply from aggregated individual technologies must follow the heat demand (MJ/s)}

$$
L_{j, g} p_{t}=h_{j, g}^{t} \forall j \in I N D, g \in G^{I N D}, t
$$


To prevent individual heating technologies in aggregated areas of interacting between points of consumption, such as individual households, any individual technology must follow the heat load curve over the year.

\section{Extended version of the Balmorel area level heat balance equation}

$$
\sum_{g} h_{i, g}^{t}+\sum_{j \in \operatorname{Adj}(i, j)} x_{j, i}^{t}=d_{i}^{t} / 1-\operatorname{loss}_{i}+S_{i}^{t}+\sum_{j \in A d j(j, i)} x_{j, i}^{t} / 1-\operatorname{loss}_{j} \forall i, t
$$

The heat balance in an area is defined on the supply side of the equation by the sum of local heat generation which includes unloading of storage and incoming heat distribution from an adjacent area. The demand side includes gross heat demand, storage loading and outgoing heat distribution to an adjacent area.

\section{Bounds on variables}

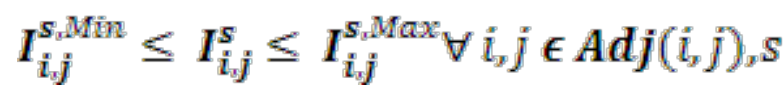

The variable for expansion of district heating is constrained by the steps defined from the heat atlas.

\section{The objective function}

minimize $Z=($ Standard Balmorel cost function $)+\sum_{t} \sum_{(i, j) \in A d j(i, j)} a C_{i, j}^{s} I_{i, j}^{s}$

The standard Balmorel objective function is to minimize the total cost of operation and investment in heat and electricity generation, transmission and distribution less net-gains (losses) in consumer utility from deviations from nominal demand. The costs of generation on individual technologies fall within the original formulation. However, the cost of the annualized cost of network expansion is added to the objective function.

Additional standard Balmorel model sets, parameters, variables, equations and bounds are described in Ravn [19].

\section{Main assumptions}

In this section some of the main assumptions used for modelling are documented. Fuel prices are one of the main assumptions. As illustrated in Table 2 the prices used differ depending on the customer type. Apart from taxes, support for renewable energy is included for Denmark in the Regulation scenario. This consists of an electricity production support of $2 \mathrm{EURc} / \mathrm{kWh}$ produced on biomass and support for electricity from wind of 3,4 EURc/kWh in a limited number of hours. Electricity produced from biogas receive 5,4 EURc/kWh in hours with high electricity prices with a maximum total price of $10,8 \mathrm{EURc} / \mathrm{kWh}$. The support is regulated with inflation. 
Table 2. Fuel prices and taxes

\begin{tabular}{lrcccccc}
\hline \multicolumn{1}{c}{ EUR/GJ } & $\begin{array}{c}\text { Market } \\
\text { price }\end{array}$ & $\begin{array}{c}\text { Central } \\
\text { plant }\end{array}$ & $\begin{array}{c}\text { Decentra- } \\
\text { lised plant }\end{array}$ & $\begin{array}{c}\text { Individual } \\
\text { consumer }\end{array}$ & $\begin{array}{c}\text { Energy- } \\
\text { and CO } \\
\text { tax }\end{array}$ & $\begin{array}{c}\text { Max tax } \\
\text { on district } \\
\text { heat }\end{array}$ & $\begin{array}{c}\mathrm{CO}_{2} \\
\text { quota } \\
\text { cost }\end{array}$ \\
\hline Natural gas & 9.4 & 9.7 & 10.5 & 12.5 & 8.7 & 7.6 & 1.7 \\
Coal & 3.5 & 3.7 & 3.7 & & 9.5 & 7.6 & 3.0 \\
Wood waste & 6.6 & 6.8 & 6.8 & & 0.0 & 7.6 & \\
Wood pellets & 9.8 & 10.1 & 10.1 & 16.5 & 0.0 & 7.6 & \\
Electricity & 20.5 & & & 21.9 & 22.7 & 7.6 & \\
\hline
\end{tabular}

Technology data including costs and efficiencies for selected technologies are illustrated in Table 3. The main references for the table are from the Danish Energy Agency [22-24], IEA $[25,26]$ and the "Heatplan Denmark" project [21].

Table 3. Technology data

\begin{tabular}{|c|c|c|c|c|c|c|}
\hline & $\begin{array}{l}\text { Ind. HP } \\
\text { air/water }\end{array}$ & $\begin{array}{c}\text { Ind. HP } \\
\text { earth/water }\end{array}$ & $\begin{array}{c}\text { Natural } \\
\text { gas CHP }\end{array}$ & $\begin{array}{l}\text { District } \\
\text { heat HP }\end{array}$ & $\begin{array}{l}\text { Coal } \\
\text { CHP }\end{array}$ & $\begin{array}{c}\text { Biomass } \\
\text { CHP }\end{array}$ \\
\hline $\begin{array}{l}\text { Investment } \\
\text { (MEUR/MW*) }\end{array}$ & 1.07 & 1.45 & 1.08 & 0.77 & 1.29 & 1.40 \\
\hline Lifetime (years) & 20.0 & 20.0 & 20.0 & 20.0 & 20.0 & 20.0 \\
\hline $\begin{array}{l}\text { Grid loss district } \\
\text { heat (\%) }\end{array}$ & 0.0 & 0.0 & 0.2 & 0.2 & 0.2 & 0.2 \\
\hline $\begin{array}{l}\text { Electrical } \\
\text { efficiency }\end{array}$ & 0.00 & 0.00 & 0.45 & 0.00 & 0.42 & 0.39 \\
\hline Heat efficiency & 2.36 & 3.29 & 0.45 & 3.50 & 0.45 & 0.51 \\
\hline $\begin{array}{l}\text { Fixed O\&M } \\
\text { (EUR/year) }\end{array}$ & 80.5 & 53.7 & 48469.8 & 1194.6 & 17234.9 & 26926.2 \\
\hline
\end{tabular}

* MW for CHP plants else $\mathrm{MW}_{\text {th }}$

The North European countries have a well established market for electricity of which Denmark form part. To be able to take electricity trade with neighbouring countries into account, the energy systems of these countries form part of the present energy system analysis. The analysis hence includes the Nordic energy system and Germany. The assumptions regarding resource potentials and energy demands are illustrated in Table 4. The biomass and waste potentials in Norway have been neglected in the present analysis as cheaper alternatives are available and the resources prove not to be used in the model anyway. 
Table 4. Domestic resource potentials and energy demands

\begin{tabular}{|c|c|c|c|c|c|c|}
\hline & & Denmark & Norway & Sweden & Finland & Germany \\
\hline Wind (MW) & & 7638 & 14000 & 18000 & 12100 & 64500 \\
\hline Straw (PJ) & & 36 & 0 & 237 & 91 & 200 \\
\hline Biogas (PJ) & & 35 & 0 & 20 & 14 & 171 \\
\hline Wood chips (PJ) & & 18 & 0 & 64 & 52 & 472 \\
\hline Wood waste (PJ) & & n.a. & n.a. & 90 & 120 & n.a. \\
\hline Municipal waste (PJ) & & 43 & 0 & 56 & 29 & 591 \\
\hline $\begin{array}{l}\text { Electricity demand } \\
\text { (excl. HP) (TWh) }\end{array}$ & & 35 & 132 & 152 & 99 & 614 \\
\hline $\begin{array}{l}\text { District heat demand } \\
\text { (PJ) }\end{array}$ & $\begin{array}{l}\text { High } \\
\text { Low }\end{array}$ & $\begin{array}{l}199 \\
139\end{array}$ & 9 & 176 & 134 & 339 \\
\hline $\begin{array}{l}\text { Potential new district } \\
\text { heat demand }(\mathrm{TJ})\end{array}$ & & 36 & n.a. & n.a. & n.a. & n.a. \\
\hline
\end{tabular}

A max potential has been applied for biogas rather than a fuel cost, as the biogas is assumed to be a waste product. If local potentials for biomass are fully exploited it is assumed possible to buy wood pellets on the world market at a higher price than the local biomass resources (See Table 2). The max wind potentials reflect an estimate of what it is realistically feasible to have installed by 2025. The potential new district heat demand has been calculated based on the heat atlas as described above.

Generalized assumptions regarding decommissioning are made for the countries surrounding Denmark. In the Nordic countries a yearly decommissioning rate of $3 \%$ is assumed for the thermal production capacity. In Germany an expected lifetime of 40 years is assumed for similar plants. No decommissioning is assumed for the hydropower plants. The nuclear power plants in Germany are expected to be phased out gradually until it is completely decommissioned after 40 years lifetime, while Sweden maintains the current level of nuclear power. It is only allowed to invest in new nuclear capacity in Finland where the upper limit is set to $1600 \mathrm{MW}$ equaling one new plant apart from the one being built at the moment.

\section{Energy scenarios}

Three scenarios have been developed for the Danish energy system in 2025 as illustrated in Table 5. The scenarios have been developed to be able to analyze the interaction between the electricity market and district heating and to uncover the consequence of significant heat savings as well as the significance of taxes and support mechanisms. 
Table 5. Scenarios for the Danish energy system in 2025

\begin{tabular}{ll}
\hline Name & Description \\
\hline $\begin{array}{l}\text { Reference } \\
\text { scenario }\end{array}$ & $\begin{array}{l}\text { Maintaining EU obligation to cover 30\% of energy consumption with } \\
\text { renewable energy while reducing energy consumption with 20\% compared } \\
\text { to 2006 ("High" heat consumption). Excluding taxes and support. }\end{array}$ \\
\hline $\begin{array}{l}\text { Savings } \\
\text { scenario }\end{array}$ & $\begin{array}{l}\text { Reference scenario including reduction of heat consumption with 45\% in } \\
2025 \text { compared to 2006 ("Low" heat consumption). Excluding taxes and } \\
\text { support. }\end{array}$ \\
\hline $\begin{array}{l}\text { Regulation } \\
\text { scenario }\end{array}$ & $\begin{array}{l}\text { Reference scenario ("High" heat consumption). Including current taxes and } \\
\text { support. }\end{array}$ \\
\hline
\end{tabular}

\section{Results}

Below the resulting electricity production is shown for each country in the total energy system analysed (See Figure 3). To be able to compare, although the sizes of production vary greatly among the countries, the results are expressed in terms of percentages of total electricity production in each country. The results are based on the remaining power plants and the new capacities found through optimization of the system. The changes in energy systems of the neighbouring countries are relevant as e.g. an increase in electricity demand in Denmark may be covered by a production unit in a neighbouring country if this is most cost efficient.

The most dramatic change occurs in Germany where the use of coal increases at the expense of use of lignite and nuclear power. The use of coal also increases in Sweden - albeit to a lesser extent, whereas it decreases in Denmark. Furthermore, wind power expands in all countries apart from Finland.

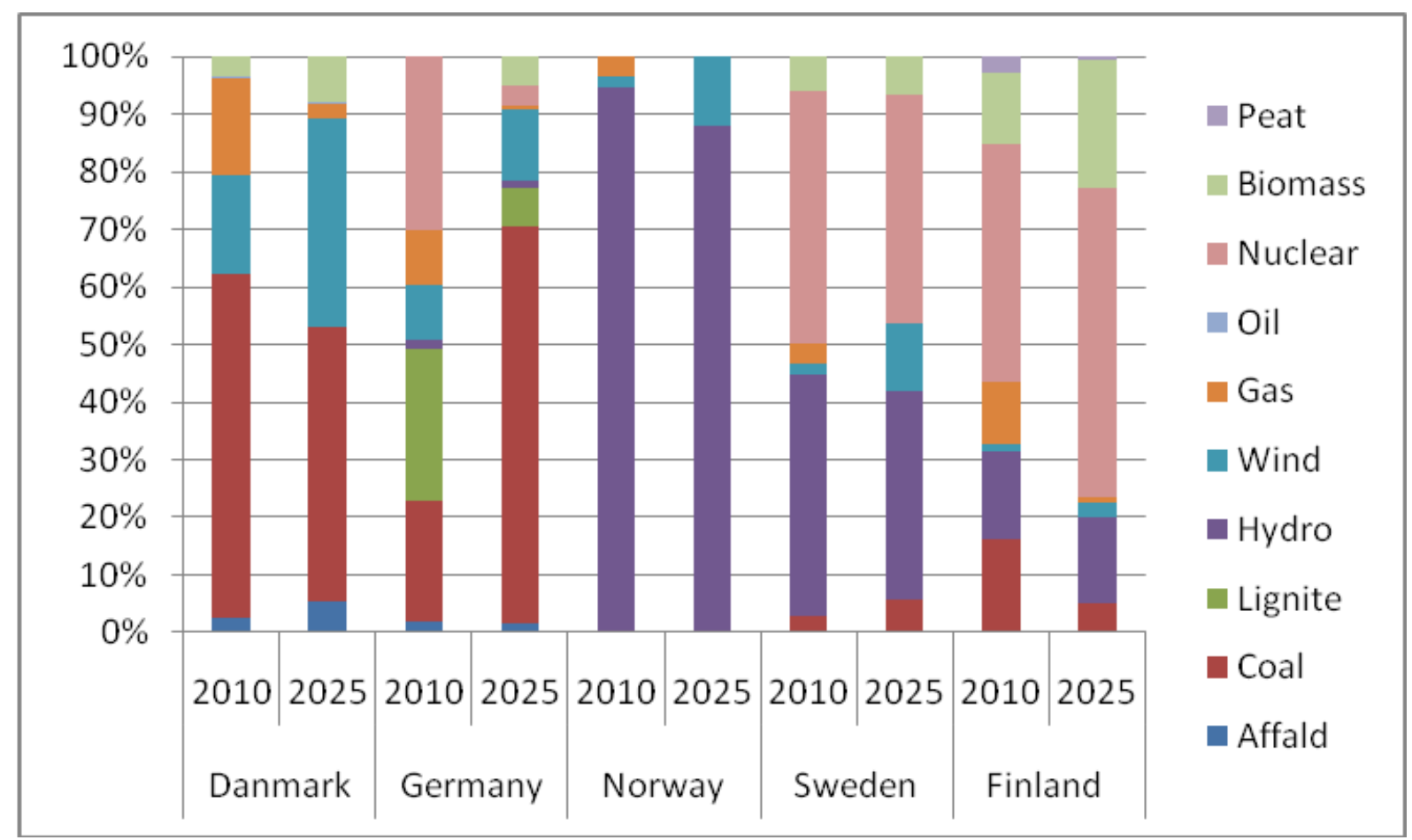

Figure 3. Resulting electricity production in the Reference scenario 
A closer view on the electricity production and export in Denmark is shown in Table 6. In 2025 a significant reduction occurs in the condense-based electricity production in the reference scenario in Denmark. The amount of wind power increases with 75\% over 15 years while the national electricity consumption increases. Overall the Danish electricity production decreases while the national electricity consumption increases. One of the reasons for the increased electricity consumption is the increased use of electricity for production of heat. In 2010 a significant electricity export is found from Denmark. This is somewhat higher than what is actually found in an average year at the moment. The net export does however turn to a net import in 2025. This happens in all scenarios apart from the Regulation scenario where the existing taxes and support mechanisms encourage more production of electricity in Denmark and where it is infeasible to convert electricity to heat. The main reason for increased net export and decreased condense-based electricity production is that the support mechanisms make it feasible to establish offshore wind power capacity.

Table 6. Electricity production and consumption in Denmark

\begin{tabular}{lcccc}
\hline Scenario & \multicolumn{2}{c}{ Reference } & Saving & Regulation \\
\hline Electricity (TWh) & 2010 & 2025 & 2025 & 2025 \\
\hline Production & & & & \\
- - Combined heat & 20 & 20 & 13 & 20 \\
$\quad$ and power plant & & & & \\
- Condensing & 17 & 8 & 12 & 8 \\
$\quad$ power plant & 8 & 14 & 14 & 22 \\
- Wind power & 45 & 41 & 38 & 49 \\
- Total & 9 & -5 & -6 & 5 \\
Net export & 36 & 46 & 44 & 44 \\
Consumption & & &
\end{tabular}

In the Savings scenario a decrease in the condense-based electricity production also occurs along with a decrease in CHP production. This is mainly due to the decreased heat consumption. A larger decrease in net export is found here than in the Reference scenario. The total electricity production is somewhat lower than in the Reference scenario, but the electricity consumption also has a lower increase.

Figure 4 shows the resulting district heat consumption in West and East Denmark. The two regions have weak electricity transmission link and are therefore modelled as separate regions. Only in some of district heating areas, which form part of each region, is the identified district heating potential fully used. While 68\% of the potential for district heating expansion is used in West Denmark, only $40 \%$ of the potential is used in East Denmark among other things due to higher expansion costs. Almost $70 \%$ of the expansion potential in East Denmark is found in the Greater Copenhagen area. 


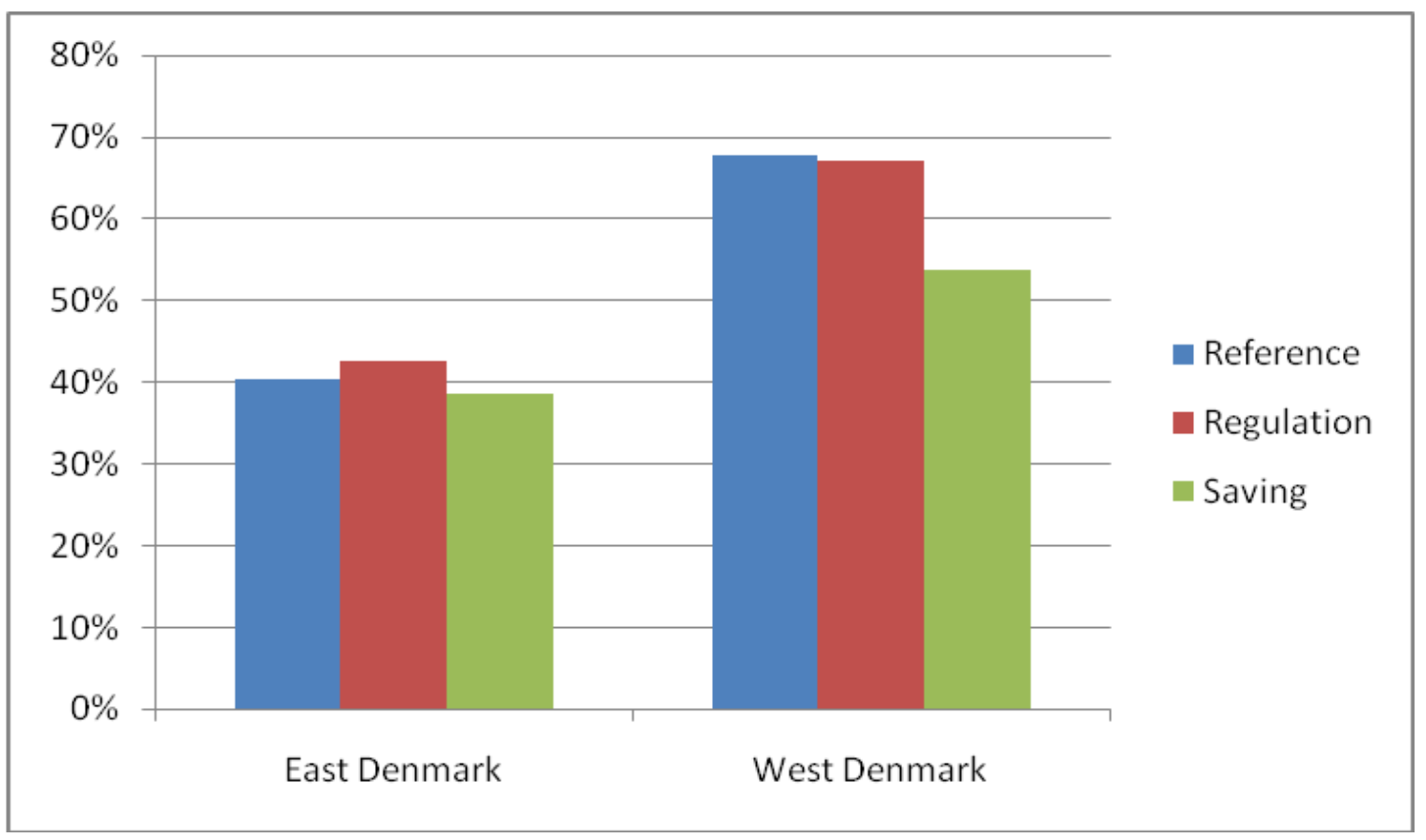

Figure 4. Resulting district heating consumption in East and West Denmark in percentage of identified district heating expansion potential

West Denmark has extensive decentralized CHP production of which many smaller plants are grouped as "small gas fired plants". In the Reference scenario around 2.1 PJ of annual heat consumption is added to the district heating network in these areas through expansion of the grid due to increased use of biogas. In the larger cities the expansion of the district heating is of 700-1200 TH annual consumption. The middle range cities also experience significant grid extensions covering around $2000 \mathrm{TJ}$ annual consumption. This group of cities has a relatively high share of heat based on waste in the model. Overall in West Denmark and in most city areas the expansions of the district heating is similar in the Reference and the Regulation scenario. In the Savings scenario some of these expansions however become infeasible.

The resulting heat production in Denmark in the three 2025 scenarios and in 2010 is shown in Figure 5. On an average $21 \%$ heat savings are implemented country wide. The individual heat production changes from being based on oil and natural gas in 2010 to be based on heat pumps in all the scenarios for 2025. In the Reference scenario the use of biomass and biogas for district heating increases from 2010 to 2025. There is an increase of $4 \%$ points in the share of waste based heat and use of electricity for heat pumps and electrical heaters has been introduced. The share of natural gas is significantly reduced and oil is no longer used. Under the given assumptions the share of district heating increases from $46.5 \%$ in 2010 to $55-57 \%$ in the scenarios. Exploiting the potential of geothermal heat and industrial waste heat may make it feasible to expand the share of district heating even further. 


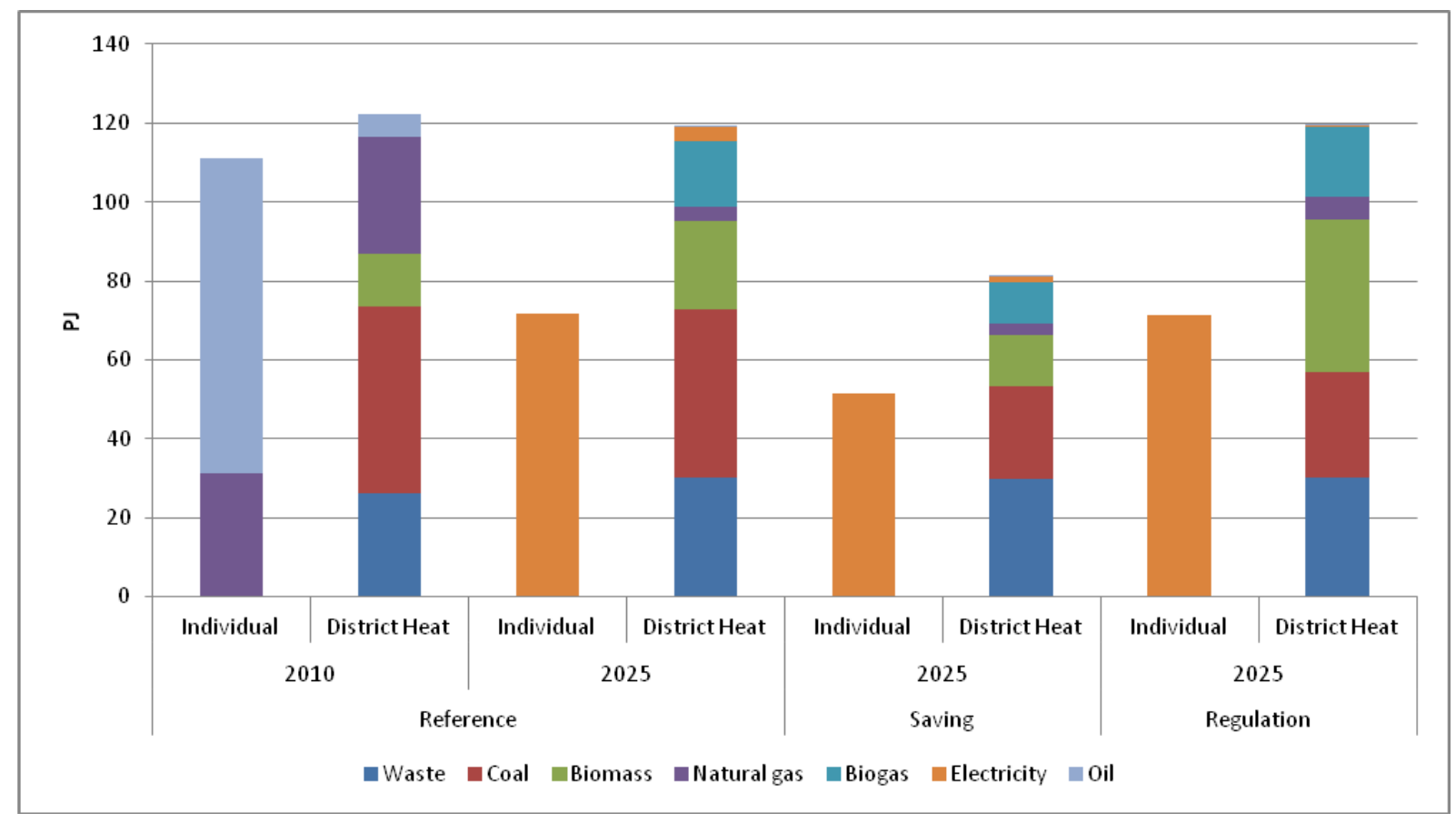

Figure 5. Heat production in Denmark

That it is feasible to expand district heating networks is supported by several optimization studies done at local level $[6,8-12,27]$. Similar shares of district heating have also been found. Persson and Werner hence finds it feasible to expand the average current district heating share from $21 \%$ to around $60 \%$ when analyzing 83 cities in Belgium, Germany, France, and the Netherlands [9].

On the other hand when comparing alternative scenarios at a national level Lund et. al. identifies the feasible district heating share to be between 50 and $70 \%$ of the heat demand in a future Danish energy system compared to the current $46 \%$ [11,12]. They furthermore find that individual oil or gas fired boilers are substituted by either district heating close to cities or by heat pumps in areas with less heat density per square kilometre, which also supports the conclusions of this article.

\section{Sensitivity analyses}

Different sensitivity analyses have been performed for the Reference scenario in 2025. The sensitivity analyses have been made by running the model for 2025 with stepwise variation of the parameters from $50 \%$ below to $50 \%$ above. Sensitivity analyses have been performed for the following parameters:

- Overall fuel prices

- Biomass prices

- Coal price

- $\mathrm{CO} 2$ quota price

Table 7 shows results of the sensitivity analyses. The changes are illustrated in percentage in relation to respectively district heat and individual heat production in the Reference scenario. The main change is seen with an overall increase in the fuel prices. For example at a $50 \%$ increase in the fuel prices, the district heat production decreases with $7 \%$ and the heat is 
instead covered by individual heat. Increased fuel prices make it economically feasible to invest in offshore wind power. Increased wind power production results in decreased production from CHP plants and a subsequent increase in heat production from heat pumps both for district heating, but in particular for individual heat production. The balance between the efficiency and cost of producing heat with a heat pump for district heating or for individual heating is hence determining the feasibility of expanding the district heating networks in a future with more wind power and less CHP. Utilisation of other resources for district heating such as geothermal and industrial waste heat may also have impact on the district heating grid expansion. With regard to changes in the other parameters the results are found to be robust as only negligible changes are found.

Table 7. Sensitivity analyses of changes in prices (fuel, $\mathrm{CO} 2$ quota, biomass and coal) from $-50 \%$ to $+50 \%$ resulting in changes in district heat production

\begin{tabular}{lll}
\hline & $-50 \%$ & $+50 \%$ \\
\hline Fuel price & $-0.6 \%$ & $-6.6 \%$ \\
Biomass price & $-2.6 \%$ & $-2.8 \%$ \\
Coal price & $-1.4 \%$ & $-1.7 \%$ \\
CO2 price & $-1.9 \%$ & $-0.2 \%$ \\
\hline
\end{tabular}

\section{Conclusions}

Combining the use of a heat atlas with national energy system analysis where it is possible to optimize investments in district heating networks and in supply technologies as well as in operation makes it possible to identify where the most optimal expansion may take place and in connection with which technologies. By analyzing district heating expansion seen from a national perspective it is possible to model the benefits the district heating system may provide in terms of adding flexibility to the overall energy system with respect to both utilization of heat, which would otherwise be wasted or utilization of electricity which would otherwise be wasted or exported at low rates, as well as with respect to providing storage capacity.

Overall, it can be concluded, that under the given assumptions it is economically feasible to expand the district heating networks to cover between $55 \%$ and $57 \%$ of the heat consumption, although substantial heat saving measures are installed. It is however not feasible to expand to $100 \%$. The main expansions happen in larger cities with high heat density.

Furthermore, it can be concluded that district heating can cost effectively contribute to the sustainability and security of supply of future energy systems by facilitating use of heat, which may otherwise be wasted, such as waste heat from power production and heat from solar heaters. Also, district heat can assist as energy storage for the energy system. Hereby it may assist in integrating further wind power by making use of electricity in large scale heat pumps in periods when the electricity price is low due to overproduction of electricity. The analyses hence show that expansions primarily occur in areas with heat available from incineration of waste or biogas and in areas where large scale heat pumps and electric heaters are combined with increased heat storages. Furthermore, oil and gas fired boilers in individual homes are substituted completely with heat pumps for the heat consumption which remains to be individually supplied. Finally the heat production at CHP units assists in paying for the electricity peak load production thereby assisting in ensuring security of power supply. In the future this enables use of smaller base load units. 
The results are overall found to be robust to changes in fuel and CO2 quota prices. The main change found is a decrease in production of district heating when fuel prices increase, wind power production increases and heat is produced in heat pumps and in particular in individual heat pumps. The result illustrates that the results are sensitive to the assumed balance between the costs of producing heat with individual heat pumps and with district heating heat pumps.

There are a number of natural extensions to the above analyses. Thus, the socio-economical feasibility of expanding district heating networks in 2025 it could be extended by making a similar assessment in a future with 100\% renewable energy taking into account further renewable energy investment options such as geothermal heat. This is of particular interest as it has been shown that geothermal energy and wind power may be the marginal energy sources in a local future Danish renewable energy system [28]. Additionally, it could be interesting to perform assessment or optimisation of other parameters than costs, such as environmental and social factors seen in a life cycle perspective. The significance of this is for example shown by Carvalho et.al. [29] in an article illustrating that trigeneration may be an economically optimal solution, but is not necessarily optimal from an environmental viewpoint, depending on the how the affected energy is produced. Greening and Azapagic [30] have on the other hand illustrated the importance of taking into account further environmental impact factors, finding that individual heat pumps may be preferable from a climate viewpoint, but natural gas boilers will have less impact on other factors such as acidification potential. Another factor which it could be relevant to take into account could be impact on land use and occupancy as illustrated by Gómez et. al. in their article on socioeconomic impacts of renewable targets in Spain [31].

\section{Acknowledgements}

We would like to express our gratitude to Associate Professor Bernd Möller at Aalborg University for giving us access to the heat atlas which he has developed and which was used in the analysis.

The project documented in this article (Efficient district heating in the future energy system) was supported by the Danish Energy Research Programme and carried out together with the District Heating of the Future Committee of the Danish District Heating Association, whom we would like to thank for the cooperation.

\section{References}

[1] European Commission. An Energy Policy For Europe. Brussels; 2007.

[2] European Commission. Directive 2009/28/EC of the European Parliament and of the Council of 23 April 2009 on the promotion of the use of energy from renewable sources and amending and subsequently repealing Directives 2001/77/EC and 2003/30/EC. L 140/16. Official Journal of the European Union; 2009.

[3] Danish Commission on Climate Change Policy. Green Energy - the road to a Danish energy system without fossil fuels: Danish Commission on Climate Change Policy; 2010.

[4] Danish Government. Energy Strategy 2050 - from coal, oil and gas to green energy, Ministry of Climate and Energy: The Danish Ministry of Climate and Energy; 2011.

[5] Danish Energy Agency. Danish Energy Statistics 2009. Copenhagen, Denmark: Danish Energy Agency; 2010 
[6] Blesl M. Räumlich hoch aufgelöste Modellierung leitungsgebundener Energieversorgungssysteme zur Deckung des Niedertemperaturwärmebedarfs (High space-resolution modelling of pipeline bound energy-supply systems to meet low temperature heat demand), PhD. Thesis, University of Stuttgart 2002. (In German.)

[7] Bakken BH, Skjelbred HI, Wolfgang O. eTransport: Investment planning in energy supply systems with multiple energy carriers. Energy 2007;32:1676-1689.

[8] Weber C, Shah N. Optimisation based design of a district energy system for an eco-town in the United Kingdom. Energy 2011;36:1292-1308.

[9] Persson U, Werner S. Heat distribution and the future competitiveness of district heating. Applied Energy 2011;88:568-576.

[10] Chae SH, Kim SH, Yoon SG, Park S. Optimization of a waste heat utilization network in an eco-industrial park. Applied Energy 2010;87:1978-1988.

[11] Lund H, Möller B, Mathiesen BV, Dyrelund A. The role of district heating in future renewable energy systems. Energy 2010;35:1381-1390.

[12] Möller B, Lund H. Conversion of individual natural gas to district heating: Geographical studies of supply costs and consequences for the Danish energy system. Applied Energy 2010;87:1846-1857.

[13] Möller B. A heat atlas for demand and supply management in Denmark. Management of Environmental Quality: An International Journal 2008;19:467-479.

[14] Münster M, Meibom P. Long-term affected energy production of waste to energy technologies identified by use of energy system analysis. Waste Management 2010;30:2510-2519.

[15] Münster M, Meibom P. Optimization of use of waste in the future energy system. Energy 2011;36:1612-1622.

[16] Möller B. Geographical information systems for energy planning (Geografiske informations-systemer i energiplanlægningen - Interaktion af geografiske metoder i lokale og landsdækkende energisystemanalyser) 2003.

[17] Danish Enterprise and Construction Authority (EBST). National Building and Dwelling Register. BBR; 2006.

[18] Danish Energy Agency. Danish Energy Statistics 2008. Copenhagen, Denmark: Danish Energy Agency; 2009

[19] Ravn H. Balmorel: A Model for Analyses of the Electricity and CHP Markets in the Baltic Sea Region. Denmark: ElkraftSystem; 2001.

[20] GAMS Development Corporation. The General Algebraic Modeling System (GAMS). GAMS Development Corporation 2011.

[21] Dyrelund A, Lund H, Möller B, Mathiesen BV, Fafner K, Knudsen Set al. Heatplan Denmark (Varmeplan Danmark). Project 2008 - 01. Kolding, Denmark: Danish District Heating Association; 2008 (In Danish).

[22] Danish Energy Agency, ElkraftSystem, Eltra. Technology Data for Electricity and Heat Generating Plants. Copenhagen: Danish Energy Agency; 2005

[23] Danish Energy Agency. Perspektiver for den danske varmeforsyning frem mod 2025 Teknisk Baggrundsrapport til Energistrategi 2025 (Perspectives for the Danish heat supply towards 2025 - Technical background report for the Energy Strategy 2025). Copenhagen, Denmark: Danish Energy Agency; 2005 (In Danish).

[24] Danish Energy Agency. Havmøllehandlingsplan 2008 - Opfølgning på kortlægningsrapporten "Fremtidens havmølleplaceringer - 2025" (Offshore Wind Turbine Action Plan 2008). Danish Energy Agency; 2008.

[25] International Energy Agency. RECaBS - Renewable Energy Costs And Benefits for Society. IEA; 2007.

[26] International Energy Agency. Energy Technology Perspectives 2008. IEA; 2008. 
[27] Lozano MA, Ramos JC, Serra LM. Cost optimization of the design of CHCP (combined heat, cooling and power) systems under legal constraints. Energy 2010;35:794-805.

[28] Østergaard P, Mathiesen BV, Möller B, Lund H. A renewable energy scenario for Aalborg Municipality based on low-temperature geothermal heat, wind power and biomass. Energy 2010;35:4892-4901.

[29] Carvalho M, Serra LM, Lozano MA. Geographic evaluation of trigeneration systems in the tertiary sector. Effect of climatic and electricity supply conditions. Energy 2011;36:19311939.

[30] Greening B, Azapagic A. Domestic heat pumps: Life cycle environmental impacts and potential implications for the UK. Energy 2012;39:205-217.

[31] Gomez A, Zubizarreta J, Dopazo C, Fueyo N. Spanish energy roadmap to 2020: Socioeconomic implications of renewable targets. Energy 2011;36:1973-1985. 